\title{
ULS at NYC: Identifying ourselves as leaders
}

\section{Message from the chair}

In New York the University Libraries Section (ULS) of ACRL sponsored programs and cliscussions that challenged academic librarians to take charge of their futures. The main ULS program focused on the individual librarian's career of the future. More than 300 people from all types of libraries attended this program (see report below). ULS discussion groups addressed ways to provide leadership at our institutions.

The meetings of the ULS committees and discussion groups were very productive, resulting in a good number of ideas and recommendations. The representatives of the 6,000-plus members of ULS were articulate, informed, and willing to move ahead.

ACRL conducted special orientation/leadership sessions for the chairs of the sections. Among the issues discussed was the implementation of ACRL's Strategic Plan. As a result, we've asked the ULS Policy and Planning Committee to focus on ways that ULS can strategically support and move ahead with the elements of the plan. The committee will explore issues of leadership as well as a sense of identity for ULS. We'll also look at ways to build positive bridges with the College Libraries Section.

The ULS Program Planning Committee is developing an exciting program for the 1997 conference tentatively titled "The New Generation of Scholars: Do They Need Us? (Maybe, Maybe Not)." How relevant are academic libraries, as scholars and students work in increasingly digital, collaborative environments?-Don Frank, Chair, University Libraries Section, Geongia Institute of Technologv

\section{That's not what I was hired to do}

"Are you doing the work today you thought you'd be doing when you were in library school?" So asked Deanna Marcum (president of the Council on Library Resources) as she led off the timely and thought-provoking ULS program entitled "That's Not What I Was Hired to Do: The Future of Your Career and Your Career in the Future." Appealing to veteran professionals and recent graduates alike, this
New York conference session furthered the ALA Midwinter discussions on facing change. While Midwinter focused on the organization, this conference challenged the individual. "That's not what I was hired to do" brought together speakers Marcum and Tom Shaughnessy (University of Minnesota-Twin Cities) and moderator Maureen Sullivan (Association of Research Libraries), who began public consideration of what is and what will be professional competence, and the skills and knowledge necessary to achieve it.

Shaughnessy and Marcum analyzed the new environment in which we find ourselves, and having to do things we were not trained to do-from managing and building customer relations to managing vendor relations, from working in teams to doing process redesign and group facilitation, from measuring and evaluating library outcomes (not simply inputs and transactions) to creating electronic texts.

Taking a theoretical approach, Marcum described a continuum of professional orientation: moving from where we once were as "technical doers" (clefined by "here is what I have, use it") to becoming service providers, then resource managers, then overseers of integrated resources. While none of these is a discreet state, the roles are somewhat telescoping, where it is necessary to understand the requirements of one in order to function effectively in the subsequent ones. The service provicler focuses on services and must have an orientation to systems thinking. Service providers understand they do not have to be experts in fields they are responsible for, but they do have to know the key issues.

Resource managers, expanding beyond the service provider, have significant managerial responsibility with people, technology, and information assets, and must move away from compartmentalization toward integrated functions. They understand their role is not about technology or information but rather about support of users and how, through planning, managing of the budget, and pursuit of institutional goals, this can be done. The overseers of integrated resources are boundary 
spanners who have the ability to think discontinuously. They understand institutional goals (beyond the library) and participate in defining them, then shape the budget and reengineer the processes to meet these.

Marcum suggests that library education must be reconstructed in light of these roles and that lifelong learning will be essential. Library professionals must have the skills to function in a multimedia environment and must move from being catalogers to being architects of systems and assessors of information. Our skills must range from understanding scholarly communication in various disciplines, to undertaking cost and benefit analyses. While we must have enough knowledge of intellectual property consiclerations and computer systems to make sound managerial decisions, we must be able to foster the capabilities of our library staff, since technology is not a substitute for people.

Shaughnessy's analysis expanded on the importance of the incliviclual; he asked where do the obligation and capacity for effecting individual change lie: with the individual? with the organization? and in what degree? He suggests that adapting to new conditions it is not simply a matter of learning new things but also a necessity of giving up what was, of changing how individuals see themselves. The issues to be faced in this regard are the interrelatedness of personal with professional identity; of how, in a changing environment, individual expertise appears to be devalued, which leads to a loss of self-esteem and a sense of being betrayed by the organization. Libraries need to grow their own expertise (since putting poor performers aside or hiring replacement staff are seldom options today). In order to grow expertise, organizations have to become true learning environments in which staff development is a daily event. Ieveloping leadership wherever it can be found and more mentoring of existing staff are important. (Think of recruiting mentors outside the library). Creating an environment where individuals can take risks without dire consequences and giving staff incentives to change are part of the challenge.

Shaughnessy's concluding observation, a point echoed and expanded on by moderator Sullivan, was that while the organization may be responsible for an individual's career development, individuals are responsible for their own well being, part of which is professional. The individual is responsible for being a perpetual learner and for adopting a positive attitude toward learning. The individual must take responsibility for accepting change and for adapting to surprises.

For a review of the overhead slides used in this session, see the ULS program Web page: http://www.sc.edu/library/ala/index.html.Deborah B. Dancik, University of Alberta

\section{Other conference news}

"Giving Away the Farm: Academic Material on a Commercial Internet" was the topic of the ULS Librarians in Higher Education and Campus Administration Discussion Group led by Jerry D. Camplell (University of Southem California). From the 19th-century view of a shared mission between publishers and academics to disseminate scholarly information, we have moved to an environment in which publishers and academics no longer share this vision. Campbell thinks academics must retain rights to the research material they create and should institute a not-for-profit consortium for the exchange of scholarly information. A lively discussion ensued, touching on issues of copyright, electronic scholarly publishing, and implications for academic libraries.

In the Discussion Group for Public Service Directors of Large Iniversity Libraries program, "The Blurring of Lines between Public Services, Technical Services, and Collection Development," members discussed: collaboration amidst complexity; working across the structure while maintaining expertise; customer-driven libraries leading to more crossfunctional services; frontline staff connected to experts throughout the library as a model for the best customer service.

The second agenda topic was "Electronic Text Access and Printing." Various institutions reported that they are investigating methods and software to mount full-text reserves on the Web and to set up print servers. The round robin question for the meeting asked everyone for their top two issues or concerns, yielding this list: customer service training; electronic text delivery and printing; alternate ways of providing reference; interface design; consolidation of service points; downsizing and restructuring staff; offsite storage and onsite compact storage--Paula Walker; University of Wasbington, Seatle 